I OBITUARIO

\title{
Mario Ruiz Sanz. In memoriam.
}

(Montesa, 27-3-1967- Valencia, 29-4-2018)

\author{
José García Añón \\ Director General de Reformas Democráticas y Acceso a la Justica \\ Generalitat Valenciana
}

Resulta difícil hablar de alguien con la falta de sosiego que produce su ausencia y, al mismo tiempo, la necesidad de hacerlo presente.

Mario fue Profesor titular de Filosofía del derecho, acreditado Catedrático, en su último destino, la Universitat de València, $y$ anteriormente en distintas posiciones y cargos en la Universitat Rovira i Virgili de Tarragona, donde desarrolló gran parte de su carrera académica. Fue también director del Anuario de Filosofia el Derecho y de los Cuadernos Electrónicos de Filosofía del Derecho.

Formó parte de la "escuela de Valencia", si así se puede llamar al grupo de académicos que, con el impulso y dirección del profesor Javier de Lucas, ha dedicado su investigación a la ardua tarea de profundizar en la "lucha" por los derechos humanos, y que se constituyó en el actual Institut Universitari de Drets Humans que es referente en el ámbito nacional e internacional, por ejemplo a través de la "Red Tiempo de los Derechos" (HURI-AGE).
Además de la docencia en estas materias, investigó y publicó un buen número de trabajos sobre las que fueron algunas de sus preocupaciones: los problemas de la teoría del Derecho, la argumentación jurídica, los derechos humanos en las sociedades multiculturales o la justicia ambiental. Todo eso y mucho más es lo que fue y lo que nos queda.

Por eso no quisiera con este breve recuerdo hacer una semblanza académica exhaustiva, que podría resultar injusta, y solo señalar algunos aspectos personales relacionados con su quehacer profesional que difícilmente se podrán encontrar si uno hace una búsqueda en internet o si recopila sus trabajos encima de la mesa de trabajo.

Comenzaría diciendo algo que debe enmarcar todo lo demás: los sobresaltos de su larga enfermedad no impidieron en ningún momento, sino todo lo contrario, la agudeza de juicio, la sarcástica provocadora ironía y la erudición transgresora.

A ello añadiría que Mario no hubiera querido figurar en la "Sección necrológica" de una revista 
o un periódico. Al menos, en la forma usual, como un recuerdo más en los que la familia, los colegas y los amigos manifestamos el razonable dolor y el imborrable recuerdo. Quizás, si fuera necesario escribir una esquela, diría algo así recordando su congelada sonrisa: "Gracias, gracias, me lo he pasado lo mejor que he podido...".

Por este motivo me gustaría destacar al retratarlo como de una erudición transgresora, genio $\mathrm{y}$ figura exigente, con la puntilla siempre dispuesta y por ello, un gusto peculiar por la música, la literatura y, sin duda, el lenguaje cinematográfico.

Esto podría explicar y hacer entender algunas de las anécdotas que me vienen a la memoria. Así por ejemplo, solía quemar un código de derecho penal en clase para explicar la crítica a la ciencia del derecho de von Kirchmann y su conocida expresión de que tres palabras rectificadoras del legislador pueden destruir bibliotecas enteras. Era su mejor manera de hacer entender la posición del jurista alemán, además de que ese recuerdo permanecería indeleble en la memoria de los egresados que asistieron a sus clases.

Era un descreído de la llamada "innovación docente" a la que, por otra parte, contribuía con gusto con su incursión en el cine para poder explicar, entender y formar en el Derecho. Mario, nos hacía ver lo que no solíamos ver, llegando con precisión hasta los ínfimos detalles. Por cierto, amante del cine de lo más insospechado era posiblemente el único comprador en unos conocidos grandes almacenes de cintas VHS de películas chinas subtituladas solo en ese idioma.

La exigencia de mejora y su perfeccionismo no solo se podía plasmar en la crítica sarcástica que prodigaba sino también en la búsqueda de la excelencia, si así se puede llamar. Como ejemplo, consiguió junto con sus respectivos equipos el Sello de Calidad de la Fundación Española para la Ciencia y la Tecnología (FECYT) para las dos revistas que dirigió, al igual que el reconocimiento de otros organismos internacionales. Como nos dijo en su momento con una solemnidad que le trascendía: "quisiera transmitir (a pesar de que parezca una cursilada) que nunca hay que rendirse ante las dificultades, y que buena muestra de ello es este premio. Pero hay que seguir trabajando para mejorar aun más..."

Era también un escudriñador pertinaz de lo estrambótico, como cuando localizó aquella inscripción de la "Fundación Marquesa de Balboa Ancianos Solitarios Venidos a Menos" en el Registro de Fundaciones del Ministerio de Sanidad y Politica Social o algunas decisiones judiciales que no podría reproducir aquí demostrando que existen muchas realidades posibles que superan cualquier ficción. 
Compartía y era una ayuda inigualable para encontrar la última bibliografía sobre cualquier tema y conocía los entresijos de cualquier autor de la asignatura y de las demás también. No era raro que, de tanto en tanto, se dirigiera a nosotros así: he localizado un articulo impresionante, tanto que va a cambiar vuestra concepción no solo de la filosofía del derecho, sino del sentido de la vida.

Crítico y feroz con el estado de la filosofía del Derecho actual fue capaz de señalar que lo genial se puede encontrar en lo inaudito y excéntrico. Esto siempre me ha sonado, en estos tiempos confusos, en una reivindicación de la libertad en su sentido más puro e incontestable.

Estos días he releído sus correos y mensajes, y aunque parezca difícil de creer, he de decir que me lo he pasado bien recordando al Mario kitsch, retorcido y provocador. Sus textos siguen siendo desternillantes e incisivos y, al mismo tiempo, envuelven en una coraza la debilidad de la condición humana y la fragilidad de la salud abocada a un triste final.

Cuando un amigo nos abandona joven y en plenitud pensamos sobre todo lo que pudimos haber compartido y lo que nos vamos a perder. Pero también nos quedan todas las peripecias que forman parte de lo que seguimos siendo con él. 